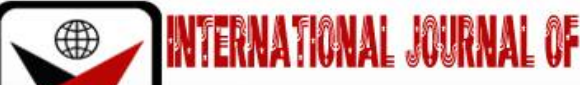

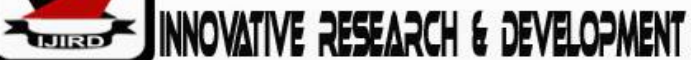

ISSN 2278 - 0211 (Online)

\section{The Effects of Collaborative Writing Strategies on Malaysian ESL Learners' Writing Fluency}

\begin{tabular}{|c|}
\hline Muhammad Nafis Azman \\
Postgraduate Students, University Kebangsaan Malaysia \\
Nur Ehsan Mohd Said \\
Senior Lecturer, Faculty of Education, UKM, Malaysia \\
\hline
\end{tabular}

\begin{abstract}
:
Difficulty in writing can be considered as one of the major common problems in ESL classroom and writing fluency is one of aspects in writing. Therefore, this study was aimed to investigate the effects of collaborative writing strategies on learners' writing fluency and the focus was on word counts, content elaboration and organization of the writing. An action research design was employed in this qualitative study. Ten form five (age 17) secondary school students in Kluang, Johor Malaysia were selected as participants and they were exposed to sequential and parallel collaborative writing strategies for 12 lessons spanning 6 weeks after their first writing task. The final writing task was conducted after the implementation of collaborating strategies.The analysis of their first and final writing tasks was used as the instruments for this study to find out the effects of collaborative writing strategies on learners' writing. The result finding showed the effects of collaborative writing strategies when learners exhibited increment of word counts, enhancement on content elaboration and proper organization of their essays. In short, collaborative writing strategies were undeniably one of the classic yet feasible and interesting strategies that teachers in this $21^{\text {st }}$ century educational setting could practise to help enhance ESL learners' writing skills.
\end{abstract}

Keywords: Collaborative writing, ESL learners, writing fluency, writing skills

\section{Introduction}

Writing fluently and effectively in English is highly demanded and essential in this modern world especially as communication and in academic setting (Biria \& Jafari, 2013; Wigglesworth et al.,2014). However, writing is considered difficult because it involves a lot operation linguistic and rhetoric which might be contributing factors to ellipsis and uncertainty (Ghufron \& Hawa, 2018). Writing process involves a lot of stages and it does not take just a lesson to produce a quality writing. Many previous studies put more focus on the accuracy of writing, so writing fluency should not be left unnoticed (Sugita, 2012). Sugita (2012) stated out of 1027 Japanese university students, 80\% of them had difficulty in writing longer paragraph, structuring their essays correctly and were not able to express their ideas well. However, Sugita (2012) highlighted many studies have only been done on accuracy of the writing and less in terms of fluency. Mat Awal, Jalaluddin, \& Ab (2011) as cited from Malaysian Education Ministry (2000), among the qualities good writing development are the presentation of ideas and ability to elaborate them into paragraphs.

Writing process can be very intricate, challenging and thought-provoking and this is one of the causes why some ESL learners are not interested to write. Writing involves many laborious tasks and students need to focus on many components to produce good and quality writing texts. Lim, Melor and Mohamed (2018) also stated that in Primary School Achievement Test (Ujian Penilaian Sekolah Rendah) required the candidates to fulfill the tasks by providing sufficient relevant content. In fact, in Malaysia Education Certificate examination or Sijil Pelajaran Malaysia (SPM), in Paper 1 section B candidates are required to write 350-word composition. ESL teachers in Malaysia has confirmed that one of the writing problems among Malaysian learners is writing development (Ghabool \& Kashef, 2014). Mat Awal et al., (2011) also conducted a study on Malay Language writing fluency and found out that one of the major writing problems was learners' inability to develop and elaborate ideas. Furthermore, Mat Awal et al. (2011) highlighted in their article that Malaysian students are incompetent to write to the expected benchmarks because they are unable to generate and elaborate the ideas or issues discussed. Ismail, Hussin, \& Darus (2012) stated in the study, it was found that the writing difficulties faced by 200 UiTM students did not acquire the skills to discuss in-depth contents. This is also supported Lim, Melor and Mohamed (2018) which stated in their study that other than unable to produce ideas, Malaysian learners especially in urban areas also had lack of interest and motivation for English writing. Ghufron (2018) stated in order to overcome writing problems, teachers should determine teaching and learning strategies that can positively affect students' writing performance.

Learning should involve interaction among peers and members of the society and this will lead someone to learn and develop his or her knowledge Vygotsky (1978). Collaborative writing strategies is has been practices and 
implemented to discover how social interactions enhance learning and understanding of the knowledge. Shehadeh (2011) stated that in the last 15-20 years collaborative work has become a common practices in ESL classrooms around the globe. This concept of collaborative writing in ESL classroom is braced by the social constructivist perspective of learning and it provides learners with a spectrum which boost them to their cognitive and linguistic development. Shehadeh (2011) and Khatib \& Hussein (2015) indicated that studies have revealed that scaffolding arises in ESL classroom context when learners work collaboratively. When learners works collaboratively to do their writing, it might help them enhance their writing skills such as writing fluency. This study however, is aimed to find out the effects of collaborative writing on word counts, the elaboration of content and organization of the essays among Malaysian secondary school learners.

\section{The Effects of Collaborative Writing}

Collaborative writing process is not only about producing the writing piece but the process and stages involved enable learners to develop critical and analytical writing skills (Ghufron, 2018). Collaborative writing involves a few stages as according to Ghufron (2018), brainstorming, drafting, revising and editing. It actually reflects on active learning that allows learners to take the ownership of their own learning. Learners participate actively in those stages of collaborative writing activity and according to (Islam et al., 2016), peer feedback and peer correction increased learners' writing fluency and accuracy. Collaborative writing activities or strategies are also able to reduce learners' anxiety to write and encourage learner's productivity in writing (Islam et al., 2016). Writing skills cannot be acquired in just a fortnight, so for learners to be able to produce a quality piece of writing involves strategies and processes. The present study focuses on three aspects of writing, which are on ideas development, word counts, and organization of the essays.

Students who write more words display the drive to achieve their writing goal (Troia, Harbaugh, Shankland, Wolbers, \& Lawrence, 2013) and sociocultural theory which was pioneered by Vygotsky is one of the key theories of collaborative writing. Social contexts is one of the crucial elements in learning and communication process (Kwan \& Yunus, 2015). Islam \& Maab (2012) stated in their research that although writing is an important language skill but learners are not motivated to write as their writing performance is very inadequate. Therefore, Islam and Maab (2012) revealed that collaborative writing creates supportive writing environment which learners relish the rooms to experience thinking process and creating ideas with their peers. Collaborative writing encourages learners to interact and express their ideas and it is crucial for learners who have problem in generating ideas to write more (Aminloo, 2013). Stell (2018) supported this idea by mentioning in her study that learners develop and create ideas through peer discussion they have during collaborative writing. It was also found out in a study conducted by Stell (2018) that collaborative writing strategies showed effects on fluency of the ideas and also the accuracy of the language used in the writing.

Furthermore, collaborative writing strategies also boost learners' ability to generate ideas and elaborate the contents of their writing. One of the writing problems faced by Malaysian learners is inability to generate ideas and elaborate their content. Shehadeh (2011) defined content as thesis development, quantity and relevance of details and coverage of topic. Lim, Melor and Mohamed (2018) stated collaborative writing strategies allow learners to gather information during brainstorming session and it also helps them to think further for their writing. Islam \& Maab (2012) conducted a study on the effect of collaborative writing, the finding revealed that during pre-writing or brainstorming session, the questions and discussion helped learners to stimulate their ideas for the writing topic they selected. Ghufron (2018) in his study on collaborative writing in ESL classroom resonated that collaborative writing activities promote thinking skills and learners are able to generate and express their ideas freely and this is crucial in creating a piece of writing. Shehadeh (2011) highlighted that collaborative writing strategies have impact on content organization and vocabulary but not on grammar. It was also discussed in Shehadeh (2011) that among the contributions of collaborative writing strategies is on length of the text produced and language forms and content.

Collaborative writing strategies also boost learners' organizational skill for their writing during the brainstorming or pre-writing process. Shehadeh (2011) mentioned that organization means organization of ideas, sequencing and clarity of the statements. Learners learn to sort out ideas which fit to the topic of their essays and sort the ideas according to the paragraph (Ghufron, 2018). Moreover, Aminloo (2013) stated from the finding of his study on collaborative writing strategies, even with simple sentences, the treatment group managed to connect their sentences and paragraphs logically and appropriately. In addition, Islam and Maab (2012) also highlighted the same idea the finding of their study because the participants exhibited $9 \%$ of improvement on the organization mean score for their writing and he mentions the participants managed to organize their ideas appropriately after the implementation of collaborative writing strategies. This shows that from collaborative writing strategies, technical element such as organization can be enhanced through collaborative writing strategies. It is crucial for learners to organize their essays because to help readers to understand one section to another and communicate the ideas well as according to Islam and Maab (2012) and Steve (2003) highlighted that one of the qualities of a good writer is when the writer is able to organize the ideas well by moving and ordering one idea to another well.

\section{Writing Fluency}

Fellner, Apple, Faculty, \& Dormer (2006) cited Brown (1994, p 113) explained the longer the flow of the writing and the more words produced, the more fluent the writer is. Fellner, Apple, Faculty, \& Dormer (2006) also higlighted in their study that writing fluency is word counts which are produced in a specific number of time and also the content approitatenes to the topic of the task. Dormer (2016) also stated similar definition as he defines writing fluency as quantitative elements of writing such as number of words and he also mentions that in wider Linguistics, other than number of words other elements of fluent writing are creativity, coherence and appropriateness. Also, as cited from Lanin (2007) by Ju A (2010), writing fluency is cohesiveness and coherence of ideas and contents in a piece of writing and a good 
organization so the readers will be able to move from one paragraph to another easily. Writing fluency is the ability to generate and develop more contents and ideas and grammatical accuracy is not the main concern (Ju A,2010). Biria \& Jafari (2013) in their study stated that a learner is a fluent writer when they are able to express and communicate their ideas and thought logically and appropriately through writing. One of writing fluency elements is the ability to expend ideas or contents logically and aware of the coherence of one idea to another (Sugita, 2012).In order to become a fluent writer, learners should be able to acquire three important components of writing fluency which are the length of their writing, the ability to organize their ideas and presented it in a coherent manner and also the ability to elaborate their ideas and opinions related to the topic. Therefore, this study had focused on three aspects of writing fluency; word counts, elaboration of ideas or contents and organization. This might help Malaysian learners to score good band in their writing, based Malaysian Examination Syndicate, the current marking rubric for SPM Paper 1 Section B, word counts, elaboration of ideas and organization are important aspects to score good writing band.

\section{Process Writing and Collaborative Writing Strategies}

Rather than focusing on the product, teachers should put more focus on the process of getting the product or the outcome because by introducing learners to the process scaffold them to build up their writing skills (Aminloo,2013). Marshan (2016) suggested a few collaborative writing strategies and parallel writing strategy is one of it when learners are assigned different part of paragraph of writing and work on their parts at the same time before all the parts are combined as written document. Sequential writing strategy is when learners are assigned different parts but when they have done with their part, they have to others to continue. These collaborative writing strategies involves a few processes or stages before the final product is ready. Ghufron (2018), Marshan 2016 and Kamal \& Faraj (2015) stated the process of collaborative writing in his study and it begins with pre writing or brainstorming where learners express and suggest their ideas before they organize the ideas. The next stage is drafting where learners start drafting their parts individually and then revising stage is when learners revise the combined parts to improve the content and clarity. The final stage is editing where the focus on spelling, grammar, punctuation and sentence structure. It is crucial for teachers to facilitate and assist learners throughout the process to help learners with feedbacks and writing models (Miftah, 2015).

\section{Research Design}

The research design adopted in this study was action research, Jean Mcniff's Model (1988) because this model allows researcher to improve and take action if it needs attention and then yield indication how and what has been improved. An action research is among numerous research designs which is commonly used in education field. This study employed an action research design because the researcher (as a teacher) was allowed to observe whether collaborative writing strategies had brought any positive effects on word counts, elaboration of the contents and organisation of the writing. This study employed sequential and parallel collaborative writing strategies (Marshan, 2016) and each strategy was employed along with process writing suggested by Ghufron (2018), Marshan (2016) and Kamal \& Faraj (2015). The participants went through sequential and parallel collaborative writing strategies as they had to write their parts and assess others' parts too. The participants also went through writing process which involved pre-writing, drafting, revising, and editing before they submitted their writings. The implementation of sequential and parallel collaborative writing strategies in writing process for 12 lessons and 6 writing tasks. For the record, all participants were familiar and exposed to writing process earlier.

\subsection{Participants}

This study was carried out in one of the national secondary schools in Johor, Malaysia. The school was located in the outskirt area of Kluang district. The participants of the study were 10 students from a form five class (age 17) and these participants were streamed to the class based on their form 4 final exam result. All of them were not native speakers of English because their L1 was Malay Language. Therefore, they were not highly proficient in English Language and they had almost similar English writing proficiency level because their writing performance band fell between Band E or U(i) as accordance to Malaysian Education Certificate English Paper 1 examination marking rubric. Band E and U(i) indicate that the writing shows incompetency in terms of number of words, organisation and limited or inadequate content.

\subsection{Research Procedure}

Before the implementation of collaborative writing strategies began, the participants completed their first writing task. The first writing task required the participants to write a 350-word length of a descriptive essay. Then, the action research was conducted for 6 weeks and these participants underwent 12 writing lessons (1 hour per lesson) with the implementation of collaborative writing strategies. The focus of this writing lesson was a descriptive writing and writing was done collaboratively. Therefore, these participants were divided into two groups and they had to work in the same group for 12 lessons. In each week, the participants were given 1 writing task and they had to complete each writing task within 2 lessons. The researcher had the role as a facilitator to guide the participants on how to delegate the task and follow the collaborative writing strategies. The strategies involved the delegation of the task, brainstorming, drafting, peer checking and final writing. After the 6-week of collaborative writing lessons were completed, the participants sat for their final writing task. Both, first and last writing task consists of the same essay question which they had to write a 350-word length of descriptive essay. 


\subsection{Data Collection and Analysis}

The instrument was used to investigate how collaborative writing strategies were able to enhance learners' writing performance was the comparison between their first and final writing tasks. There were a few criteria that were looked into. The first one was the word counts because in Malaysian Education Certificate (SPM) English Paper 1, Section $\mathrm{B}$, candidates must write minimum 350 words. One of the questions was a descriptive essay and it was the type of essay that was used for this study. If the candidates write lesser, their essay will be examined as Band-E and below essay. Then, another criterion that this study looked into was content elaboration. The last criterion was organisation of their writing. These three criteria were among the important criteria if the students aim to score good marks in SPM English Paper 1. The extracts from participants' writing were included to show recurring patterns in their writing.

\section{Result}

\subsection{The Effect of Collaborative Writing on Word Count}

\begin{tabular}{|c|c|c|c|}
\hline $\begin{array}{c}\text { Participants } \\
\text { (pseudonym) }\end{array}$ & Word Count (First writing) & Word count (Last writing) & Difference \\
\hline Farah & 240 & 580 & 340 \\
\hline Aliya & 109 & 441 & 332 \\
\hline Atiqah & 214 & 540 & 326 \\
\hline Rahman & 165 & 482 & 317 \\
\hline Puteri & 256 & 520 & 264 \\
\hline Syafiq & 205 & 469 & 264 \\
\hline Danial & 132 & 394 & 240 \\
\hline Zubaidah & 172 & 381 & 209 \\
\hline Arifah & 168 & 332 & 164 \\
\hline Zahin & 250 & 382 & 126 \\
\hline
\end{tabular}

Table 1 shows the difference of the word counts during the first writing and the last writing from the most improved to the least improved in terms of the word counts. It reveals a very significant improvement of word counts from each participant's essays. All participants wrote less than 350 words in their first writing task with Aliya had the lowest number of words which was 109 words. However, every participant had at least above 100 words increment from their first writing and they managed to fulfill the requirement of the task which to write at least 350 words except for participant which wrote 332 words in his final writing task. The most increased was Farah as the participant increased 340 words from 240 words in her first writing to 580 words after the participant underwent the implementation of collaborative writing strategies in their writing lesson. However, Aliya exhibited the most significant improvement. This participant wrote only two short paragraphs and the contents and ideas were very limited 109 words in his first writing task. However, her final writing task increased to 441 word counts with 5 paragraphs. Furthermore, Rahman also showed over 300 words of improvement in his final writing task. Puteri, Syafiq, Danial and Zubaidah showed an average improvement of word counts by having more than 200 words increment in their final writing task. Arifah and Zahin showed the least increment of less than 200 words of increment from their first writing task but their word counts in the final task did show impressive increment.

\subsection{The Effect of Collaborative Writing on Elaboration of the contents}

It was obvious that all participants were limited in terms of contents when they wrote their first writing task. The participants were aware that they were required to write at least 350 words but all of them wrote 250 words and below. Except for Puteri who wrote 4 short paragraphs, the other participants wrote a very short 3-paragraph essay. All them, concluded their essays on the third paragraph. Their content were not well elaborated as they were lacking of ideas to write. None of them planned their writing on their first writing task. Three participants could not finish their writing within the given 1 hour. However, after the implementation of collaborative writing strategies, every participant wrote five paragraphs and the main idea of each paragraph was very well elaborated. Their supporting details were not limited. For example, when they described a friend, the description was detailed and if they describe a situation, they managed to describe clearly and vividly. Table 2 presents extracts taken from some of the participants' essays and it shows how the participants improved in developing and elaborating their contents when they wrote their first and final writing tasks. From the table, it can be seen some comparison on how some of the participants elaborated their content in some of the paragraphs (on the bullying incident): 


\begin{tabular}{|c|c|}
\hline First Writing & Final Writing \\
\hline $\begin{array}{l}\text { One day, Ayu walked to the toilet with Yoe. I } \\
\text { went to the toilet and left him. I saw a few form } 5 \\
\text { students. I saw Yoe was bullied. I saw them take } \\
\text { Yoe's money from his pocket. }\end{array}$ & $\begin{array}{l}\text { Last week Ayu walked alone to the class during our } \\
\text { recess time. Out of nowhere, a group of bullies came. } \\
\text { They took Ayu's bag and threw it at the back of the } \\
\text { class! I saw Ayu was crying and I asked her why. She } \\
\text { told me the bullies asked........ }\end{array}$ \\
\hline $\begin{array}{l}\text { In conclusion, every person must help overcome } \\
\text { bullying problem. I hope there are no more } \\
\text { bullying problems and every student feels peace } \\
\text { at school. }\end{array}$ & $\begin{array}{l}\text { In conclusion, until this day bullying is still of the } \\
\text { crimes occurs in schools. Some students are bullied } \\
\text { mentally and physically and the victims are always } \\
\text { weak students. If this situation is not stopped, the } \\
\text { victims might become depressed. I hope our society } \\
\text {........... }\end{array}$ \\
\hline $\begin{array}{l}\text { In conclusion, my friend and I decided to give the } \\
\text { bully some money and asked them to buy foods. I } \\
\text { also advised him to not bully other person. - } \\
\text { Conclusion }\end{array}$ & $\begin{array}{l}\text { I felt sympathy for Andrew as he never told about his } \\
\text { ordeal to others. Because of my encouragement and } \\
\text { support, Andrew finally decided to gather his } \\
\text { courage to tell the principal. At the end, the } \\
\text { disciplinary board had to meet Ryan's parents. Ryan } \\
\text { was expelled from school due to his bad disciplinary } \\
\text { record. I hope, bullying issues will never happen in } \\
\text { the school area. }\end{array}$ \\
\hline $\begin{array}{l}\text { In conclusion, I hope nobody in school will be the } \\
\text { bully victim anymore. The bully should get } \\
\text { punished. - Conclusion }\end{array}$ & $\begin{array}{l}\text { After the change she did, no one was dare to bully } \\
\text { her. Because of that incident, she got many new } \\
\text { friends and she became closer to me. After all that } \\
\text { happened, she realised she could not always let the } \\
\text { bullies bully her. She must be brave and face the } \\
\text { bullies. I learn that I must be helpful and help those } \\
\text { who are in need. The society also needs tp spread } \\
\text { about the effects of getting bullied. }\end{array}$ \\
\hline $\begin{array}{l}\text { A person who was bullied in my school was } \\
\text { Syafiq. He was bullied because he was poor and } \\
\text { he was not clever. He was small too. - } \\
\text { Paragraph } 2\end{array}$ & $\begin{array}{l}\text { I had a friend who was very clever in the class and he } \\
\text { was always a good student. She got straight As in } \\
\text { final exam. She came from a poor family and her } \\
\text { clothes was very dirty. She was always asked by other } \\
\text { students to do their homework before she want back } \\
\text { home. That was why she was always left by the } \\
\text { school bus. She was very demotivated and sad. She } \\
\text { did not want to go to school because she was scared } \\
\text { of the bullies. }\end{array}$ \\
\hline $\begin{array}{l}\text { Next, my school also had bullying cases. I did not } \\
\text { like this one group of bullies. They always bullied } \\
\text { new students. - Paragraph } 3\end{array}$ & $\begin{array}{l}\text { Nor was always a quiet girl. She did not have close } \\
\text { friends because she somehow loved being alone. She } \\
\text { felt comfortable when she was alone. Nor was also a } \\
\text { smart girl and she always helped others in study } \\
\text { although she was a lone ranger. I admired her } \\
\text { although everyone thought she was the nerd in that } \\
\text { school. }\end{array}$ \\
\hline
\end{tabular}

Table 2

\subsection{The Effect of Collaborative Writing on the Organization of the Essay}

In Malaysian Education Certificate (SPM) examination for English Paper 1, organization is one of the criteria that is looked into when the essays are examined. Based on their first writing, except for Farah and Aliya, other participants had written only two to three paragraphs and they wrote all contents and introduction in their first and second paragraph. In addition, participants had problem in connecting their ideas appropriately from one paragraph to another as they tend to write all of main ideas in one paragraph and without any descriptions or any supporting details. Their writing seemed to be unequal in terms number of words in each paragraph. For example, except for Farah and Aliya, the other participants wrote one main idea on the first paragraph and a brief elaboration was given on the second paragraph. Those 8 participants discussed and described the character and the situation in their second paragraph and it made the second paragraph crowded and very disorganized. 8 out of 10 participants wrote only three paragraphs and they put all of their contents in those three paragraphs. All of these participants failed to fulfill the requirement of the task as they only described the person who was bullied but they did not describe how they helped the victims. This brought down their band as their essays were scored only from Band $\mathrm{E}$ as it was their poor organization in their writing.

After the implementation of collaborative writing strategies for 12 lessons, all of the participants showed improvement on the organization of their essay. All of the participants managed to organize their ideas appropriately. Every paragraph had the main idea and the main idea was elaborated very well and vividly. All of the participants successfully wrote 5 paragraphs and they started with the introduction, the description of their friend who was bullied, the event of their friend was bullied, how they helped their friend and the conclusion. Moreover, the participant connected one 
idea to another appropriately because every paragraph had its own idea and elaboration. The participants managed to observe their topic very well and put their ideas in order and this allowed better understanding of the flow of their writing. In fact, in their final writing, their ideas were presented very clearly and they managed to fulfill the requirement of the task to describe about their friend who was bullied and how they helped their friend. All participants describe how about their friends who was bullied in paragraph 2 and 3 and they mentioned how they helped the bully victim in paragraph number 4. Participants also managed to conclude their writing with their hopes for the issues and also for their friends who were bullied. The following table displays some extracts taken from the essays of the participants:

\begin{tabular}{|c|c|}
\hline \multicolumn{2}{|c|}{ Significant Changes } \\
\hline First writing & Final Writing \\
\hline $\begin{array}{l}\text { In conclusion, my friend and I decided to give the } \\
\text { bully some money and asked them to buy food and } \\
\text { some drinks. I also advised him. - Paragraph } \\
\text { 2(last), Rahman }\end{array}$ & $\begin{array}{l}\text { Andrew was my classmate since we were in the } \\
\text { primary school. He had freckles and his body was } \\
\text { small. He always wore a pair of round spectacles. I } \\
\text { seldom spoke since I knew him. He always buried } \\
\text { himself in his books wherever he was. In the class.... } \\
\text { Paragraph 2, Rahman }\end{array}$ \\
\hline $\begin{array}{l}\text { I hope nobody in school becomes the bully anymore. } \\
\text { I there are, they should be punished.- Paragraph } 3 \\
\text { (last), Puteri }\end{array}$ & $\begin{array}{l}\text { As one of her classmates, I always saw her being } \\
\text { bullied by other classmates. They always trapped } \\
\text { her by stuck of their leges and made her fall. This } \\
\text { situation got worst when they bullied her in the } \\
\text { toilet. When I followed her to the toile, I got } \\
\text { shocked when I saw a group of mean girls...... } \\
\text { - Paragraph 3, Puteri }\end{array}$ \\
\hline $\begin{array}{l}\text { At last, Ryan was expelled from the school because } \\
\text { of his bad attitude. Andrew had more self- } \\
\text { confidence and brave to face any problem.- } \\
\text { Paragraph } 3 \text { (conclusion), Danial }\end{array}$ & $\begin{array}{l}\text { "I believe, till today bully is one of the serious issues } \\
\text { among teenagers or students. Like Ryan, the bully } \\
\text { will bully other mentally or physically. They want } \\
\text { to show that they are stronger. I hope, the victim } \\
\text { like Andred will always be protected and helped. } \\
\text { Stop bullying and do something about it. } \\
\text { Conclusion, Danial }\end{array}$ \\
\hline $\begin{array}{l}\text { Arifah did not write about the details of their } \\
\text { friend in paragraph } 2 \text {. }\end{array}$ & $\begin{array}{l}\text { "I had a friend who did not like to talk to other } \\
\text { people. Her name was Rina. She came from poor } \\
\text { family. She lived near my house and she had seven } \\
\text { siblings. Every day, she would come to school with } \\
\text { her dirty and old uniform. Sometimes....- } \\
\text { Paragraph 2, Arifah }\end{array}$ \\
\hline Zahin did not write paragraph 4 . & $\begin{array}{l}\text { "Since that day, Ahmad and I would take action } \\
\text { immediately if we saw bullying incidents. Ahmad } \\
\text { and I knew the depression when the bully victim } \\
\text { face every day. They would always be afraid to be } \\
\text { in school and they could not focus on their study. } \\
\text { This would not only.....-Paragraph 2, Zahin }\end{array}$ \\
\hline
\end{tabular}

Table 3

\section{Discussion}

The findings yielded from this study revealed that collaborative writing strategies could bring positive effects on learners in enhancing their writing in terms of increasing word counts, elaboration of the contents or ideas and organization skills. First of all, the writing process that they experienced during collaborative writing strategies implementation boost learners to write more words and it also boosted learners to fulfill the requirement of the task which to write at least 350 words. Biria \& Jafari (2013) yielded the same outcome because there was an increment of 39.57 words between first and last writing mean. Most of the students are motivated by their writing competencies during their collaborative writing task and this motivates them to think when they write essays (Talib \& Cheung, 2017) and this helped the participants to fulfill 350 words requirement in their writing tasks. The participants of this study increased at least over 100 word counts in their final writing after the implementation of collaborative writing strategies and Lo \& Hyland (2007) revealed that when their participants were engaged and motivated to write, it showed that the length of their composition increased by $34 \%$. Whatever skills and writing process learners have acquired during collaborative writing task will be applied in their individual writing (Talib and Cheung, 2017). A similar finding also revealed in Pae (2011) when the result showed the participants exhibited increment in terms of number of words in their essay due to the interactive and comfortable atmosphere they had in the collaborative writing lesson. Collaborative writing strategies boosted up the interest and motivation for them to learn and acquire process writing and skills to be applied when they write individually. Troia, Harbaugh, Shankland, Wolbers, \& Lawrence (2013) in their study highlighted on boosting up interest and motivation in learners is crucial to push students to achieve their writing as for this study, the aim was for participants to fulfill the requirement of the first and final writing task. 
Moreover, another result of this study revealed that participants showed the effects of their collaborative writing on the elaboration of the content. They managed to express and expend their contents vividly and creatively. It could be seen when their word counts increased because of their ability to expand and elaborate their main ideas in each paragraph. A study carried out by Ghufron (2018) also revealed the same outcome when learners learn to defend and explain their ideas to their peers during collaborative writing task, so the same act was applied in when they write their essays. Collaborative writing strategies help learners to gather ideas and contents thus it boost the quality of the contents in their individual work (Talib \& Cheung, 2017). Collaborative writing strategies allow the participants of this study to gauge interesting ideas and it also boosted their thinking skills to come up with good contents. Even in this study, the participants not only managed to expand their contents by elaborating their main ideas but also providing supporting details and this finding was also supported by Talib \& Cheung (2017) as they concluded that the learners gain new ideas and perspectives through interaction they have during collaborative writing. Islam \& Maab (2012) and Alsubaie \& Ashuraidah (2017) also presented the similar finding with this study when learners were able to overcome their writing block issue and became more productive and mature in terms of style and content after the implementation of collaborative writing strategies. The participants felt more confident and focus on explaining their ideas on the given topic and it was also highlighted in a collaborative writing study done by (Aminloo, 2013) where learners who have undergone collaborative writing strategies treatment, the treatment group seemed to have an improvement on their content development and it might probably due to the collaboration they had with the team members during brainstorming session.

Another significant finding exhibited by the participants of this study was the polished organization of their writing as the participants experienced writing as a process which involves brainstorming, drafting, revising, and editing. During brainstorming process, participants organized their ideas and during the drafting they were able to sort their contents in the right order. It was shown in their final writing tasks when they were able to come up with 5 paragraphs of writing and each paragraph had its main ideas and the supporting details. A study carried out by Islam \& Maab (2012) also resonated the same finding when the mean score for organization of the essays among the participants improved from 64.64 percent to 73.21 percent. Furthermore, it can also be assumed from the finding that the transition from one paragraph to another was appropriate as learners were able to link one paragraph to another very well. The continuation from one main idea to another was very clear in every paragraph and Talib and Cheung (2017) supported that in previous studies, collaborative writing strategies enhanced their understanding on the coherence of a writing piece. That reflects on why the participants of this study were able to divide their writing into five paragraphs which include the introductory and conclusion paragraph. This was also revealed from a study on the effects of collaborative writing strategies done by Aminloo (2013), the finding revealed that the treatment group could link ideas and even sentences logically by using different types of connectors. Aminloo (2013) also stated that the improvement shown in the treatment group's organization in their essay was due to the team work on revising and editing process. Therefore, the result of this study has shown the effects of collaborative writing strategies on three aspects of writing fluency which are word counts, elaboration of the contents and organization of their writings.

\section{Conclusion}

The findings of the study show a positive implication on teaching and learning writing in the classroom. Firstly, collaborative writing strategies could be one of the most feasible methods that teachers can use to increase word counts, improve content elaboration and also organization of their essays. Collaborative writing strategies also promotes that working collaboratively can bring more positive effects as collaborative writing help to enhance writing skills. Furthermore, this study could bring insight for teachers to explore variety of teaching strategies such as collaborative writing strategies in order to enhance learners' motivation and improve their skills. Moreover, the curriculum and material might look into the finding of this study and consider to include collaborative writing strategies in curriculum or be part of the assessment such group project. Perhaps for future studies, primary school learners can be used as participants to see whether or not collaborative writing strategies bring the same positive effects to them. This study did not focus on the accuracy of language so, future studies are suggested to discover the impact that collaborative writing strategies can do to enhance the accuracy of writing.

\section{References}

i. Alsubaie, J., \& Ashuraidah, A. (2017). Exploring Writing Individually and Collaboratively Using Google Docs in EFL Contexts. English Language Teaching, 10(10), 10. https://doi.org/10.5539/elt.v10n10p10

ii. Aminloo, M. S. (2013). The Effect of Collaborative Writing on EFL Learners Writing Ability at Elementary Level. Journal of Language Teaching and Research, 4(4), 801-806. https://doi.org/10.4304/jltr.4.4.801-806

iii. Biria, R., \& Jafari, sahar. (2013). The Impact of Collaborative Writing on the Writing Fluency of Iranian EFL Learners. 4(1), 164-175. https://doi.org/10.4304/jltr.4.1.164-175

iv. Dormer, R. (2016). 'Fluency' in L2 Writing : A Literature Review. Kwansei Gakuin University Humanities Review, 28(2), 97-134. Retrieved from https://core.ac.uk/download/pdf/143641111.pdf

v. Fellner, T., Apple, M., Faculty, L., \& Dormer, R. (2006). 'Fluency' in L2 Writing : A Literature Review. 28(2), 97-134.

vi. Ghabool, N., \& Kashef, S. H. (2014). Investigating Malaysian ESL Students' Writing Problems on Conventions, Punctuation , and Language Use at Secondary School Level. (July 2012). https://doi.org/10.5296/jse.v2i3.1892

vii. Ghufron, M. A. (2018). A COLLABORATIVE WRITING TECHNIQUE TO IMPROVE STUDENTS' SKILL IN WRITING ARGUMENTATIVE ESSAY (A Classroom Action Research at the Fourth Semeseter Students of English Education Depart ... (February). 
viii. Ghufron, M. A., \& Hawa, M. (2018). Teaching Writing of Argumentative Essay Using Collaborative Writing Technique Viewed from Students ' Creativity : an Experimental TEACHING WRITING OF ARGUMENTATIVE ESSAY USING COLLABORATIVE WRITING TECHNIQUE VIEWED FROM STUDENTS ' CREATIVITY: AN EXPERIME. (February).

ix. Islam, U., \& Maab, K. (2012). IMPROVING THE STUDENTS' ABILTY IN WRITING DESCRIPTIVE. 2(2), 11-20.

x. Islam, U., Maab, K., Ghufron, M. A., Biria, R., Milena, A., Luna, R.,...Kyndt, E. (2016). The Correlation between the Students' Writing Motivation and the Writing Ability. 4(1), 219-237. https://doi.org/10.1080/00461520903433539

xi. Ismail, N., Hussin, S., \& Darus, S. (2012). ESl tertiary students' writing problems and needs: Suggested elements for an additional online writing program (IQ-write) for the BEL 311 course. International Journal of Learning, 18(9), 69-80. https://doi.org/10.18848/1447-9494/CGP/v18i09/47748

xii. Kamal, A., \& Faraj, A. (2015). Scaffolding EFL Students' Writing through the Writing Process Approach. 6(13), 131-142.

xiii. Khatib, M., \& Hussein, M. (2015). Language and Writing Skill : The Effect of Collaborative Writing on EFL Students ' Writing Performance. 6(1). https://doi.org/10.7575/aiac.alls.v.6n.1p.203

xiv. Lo, J., \& Hyland, F. (2007). Enhancing students' engagement and motivation in writing: The case of primary students in Hong Kong. Journal of Second Language Writing, 16(4), 219-237. https://doi.org/10.1016/j.jslw.2007.06.002

xv. Marshan, S. (2016). USING COLLABORATIVE WRITING IN TEACHING WRITING Sukirman. 2(1), 33-46.

xvi. Mat Awal, N., Jalaluddin, N., \& Ab, N. (2011). Investigating Malay Language Writing Proficiency Level Among Upper Secondary School Students Investigating Malay Language Writing Proficiency Level Among Upper Secondary School Students. (July 2017).

xvii. Miftah, M. Z. (2015). Through Writing Process Approach. 5(1), 9-24.

xviii. Pae, J.-K. (2011). Collaborative Writing versus Individual Writing : Fluency , Accuracy , Complexity , and Essay Score. 14(1), 121-148. Retrieved from http://kmjournal.bada.cc/wp-content/uploads/2013/05/14-1-5Pae.pdf

xix. Shehadeh, A. (2011). Effects and student perceptions of collaborative writing in L2. 20, $286-305$. https://doi.org/10.1016/j.jslw.2011.05.010

xx. Stell, A. (2018). Exploring the use of collaborative writing in an EFL classroom context. 4712(32), 63-97.

xxi. Sugita, Y. (2012). Enhancing Students ' Fluency in Writing : Learning to Use Transition Words. 2(1), 18-25.

xxii. Talib, T., \& Cheung, Y. L. (2017). Collaborative Writing in Classroom Instruction: A Synthesis of Recent Research. The English Teacher, 46(2), 43-57.

xxiii. Troia, G. A., Harbaugh, A. G., Shankland, R. K., Wolbers, K. A., \& Lawrence, A. M. (2013). Relationships between writing motivation, writing activity, and writing performance: Effects of grade, sex, and ability. Reading and Writing, 26(1), 17-44. https://doi.org/10.1007/s11145-012-9379-2

xxiv. Wigglesworth, G., Fardadmehr, L., Khalaji, H. R., Studies, L., International, A., Centre, A., ... Qi, L. (2014). A Study in Collaborative Writing. 1(1), 1-11. https://doi.org/10.7575/aiac.alls.v.6n.1p.203 